\title{
The Role of Jerusalem in the Revolutions against the British Occupation and the Zionists (1920-1929 AD)
}

\author{
Dr. Zakaria Ibrahim Al-Senwar* \\ Professor of Modern and Contemporary History, The Islamic University of Gaza \\ *Corresponding Author: Dr. Zakaria Ibrahim Al-Senwar, Professor of Modern and Contemporary \\ History, The Islamic University of Gaza
}

\begin{abstract}
The British army occupied Jerusalem in 1917, and the Arabs thought that Britain was a friendly country, you will give them their rights, after you deceived Sharif Hussein, and launched the Great Arab Revolt against the Ottoman Empire, the facts on the ground were otherwise, and the British bias of the Zionist movement turned out to be revolutionary.

Jerusalem had a prominent role in the revolution of the Prophet Moses shrine, which erupted in 1920, and it was a revolution, in 1921Arabs rejected the British politician's anniversary of the Balfour Declaration, On November 2, 1921. Arab rebels clashed with the Jews in Jerusalem, and the British bias appeared in dealing with the two parties.

The religious dimension had a clear role in the Al-Buraq revolution, which broke out in 1929, after years of provocation of Jews to Muslims in Jerusalem and the chanting of slogans offensive to Islam and Prophet Mohammed, and it claims Jewish ownership of the wall of Al-Buraq, extended the revolution of Al-Buraq days and the back of the British alignment Zionists also.
\end{abstract}

Keywords: Jerusalem, British Occupation, British Mandate, Zionism, Revolution Moses Shrine, Al-Buraq Revolution, and History of Modern and Contemporary Palestine.

\section{INTRODUCTION}

Arabs and the Zionists relationship in Palestine based on the conflict, Arabs launched a number of revolution against the British Mandate and the Zionists in order to obtain independence and prevent Zionist immigration to Palestine, this study aims to identify people's role in the revolution of the Prophet Moses shrine, 1921, 1929 the study of the Zionist role in these events. The researcher returned to a number of relevant Arab, Hebrew and English sources and compared between them to discover the historical truth.

British forces moved from Egypt towards Palestine and were able to occupy Gaza after strenuous attempts on 2 November 1917 and then began occupied the Palestinian cities and villages, Until it arrived in Jerusalem on December 1917 and as a result of the superiority of British forces and weak morale of the Turkish army took the British hills on the west of Jerusalem was an introduction to the occupation of the city (1)

The Jerusalem governor, Izzat Pasha, ordered the Jerusalem Mufti, Kamel al-Husseini, and the mayor Hussein al-Husseini to hand over the city to the British, and sent a letter to the British, explaining that the reason for hand over was the desire to preserve the Holy Places in this city such Church of the Resurrection and the Aqsa Mosque.(2)

Jerusalem was subject to the British military rule since 1917AD and was the first military governor of Jerusalem The general (Bill Burton), followed by (Sir Alexander Baird) He was the last military governor of Jerusalem (Sir Ronald Stores). (3)

High Commissioner British (Herbert Samuel) arrived in Palestine in 1920 AD; the military rule ended civil rule began, but Samuel was a Jew and a Zionist; it is clear he biased the Zionist movement at all levels. (4)

The Palestinians felt this bias and began to move to reject the British policies, the flow of Zionist immigration, the increase of Zionist settlement, and the city of Jerusalem played an active role in the revolutions that erupted in $1920 \mathrm{AD}, 1921 \mathrm{AD}$, and 1929, and indicate this: 


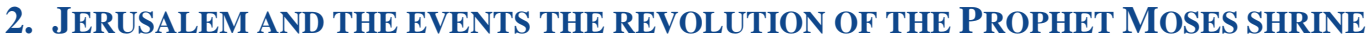

The ceremony the Prophet Moses shrine events coincided with the Muslims in Jerusalem on 4 April 1920 AD, with Easter celebrations for Jews and Christians, the friction between the two parties led to bloody events. The Arabic version differs from the Zionist version about these events, an Arab version says that the Palestinian national decided to exploit the mobilization of Muslim visitors to Jerusalem, and make it a pretend procession expressing its indignation and protest against Zionism and politics The British, when he arrived at Bab al-Khalil, the participants clashed with the Jews, Using sticks, stones, and knives, and no longer Jabotinsky and the power of Haganah, which he trained and armed they arrived, The Palestinians stoned gangs. The British police and the army intervened and took control of the situation after an hour, but the events continued in different areas for three days. (5)

Another Arab version says that while the Arabs were celebrating, Jabotinsky and members of the Haganah were harassing them, to provoke a problem, and the confrontations that had been planned by Jabotinsky had already erupted. (6)

The Zionists and the writers affected by them differ among themselves, where a team sees the Arabs attacked the Jews after incitement of chieftains to the gathering crowd, which launched quickly Towards Jewish Neighborhood, and in the next day the Arabs re-attacked the Jews, their homes, and the attacks continued three days (7), but another Zionist novel believes Jabotinsky and the leadership of Haganah decided to exploit the celebrations of Muslims, harass them to provoke them, and to be dragged into sudden bloody events, The organization of Haganah is ready for it (8), and no evidence of this is the existence of an official document of the Jabotinsky (defence) plan for Jerusalem, Jabotinsky divided components' Haganah four sets, each set limiting several areas outside old City. For his belief, the ghetto cannot be attacked never, his plan included an order for the commander of each set will seek to distribute its men to the neighbourhoods and to appoint field commanders to inspect between 8:30 and $10 \mathrm{am}$, and to keep the fourth set at the commanders' disposal; so he sent supplies as needed when the password arrives "Send Help" and, when the word "quiet" everyone must withdraw, assembly in their positions then spread.(9)

With the break out of events in Jerusalem, some five hundred Jewish youths joined the Haganah in Jerusalem, and a number of members of the city's Jewish Legion, dressed in British military uniforms, made the distinction between them and the British very difficult (10), and despite the recognition of Hebrew sources With these numbers but they The figures found that his arming was a bit (11) but a secret telegram from the British Forces General Command in Cairo was sent to the Ministry of Defense on 18 April (1920 AD), showed Haganah" had a large number of firearm and inspection of Injuries proved it. (12)

But another problem faced Haganah. When Arab demonstrators suddenly arrived at neighbourhood's Jewish a warning sounded, and two Haganah's set moved to enter the old town according to the plan from the gates of Damascus and Jaffa. But British numbers closed and surrounded and the demonstrations continued for four days, during which five Jews killed, 211 injured, four Arabs killed and 23 Arabs injured. (13) This is in the Old City, but in the new town where Haganah stationed, there's no injury.

The government declared the law, martial forbidding people to leave their homes after 6 PM, and all the newspapers disrupted, and the whole city struck, however, beatings and killings continued inside and outside the fence. There were strong rumours about the quantities of weapons hidden in Jewish and Arab homes, (14), On the seventh of April (April 1920 AD), the authorities carried out a search and arrest campaign among Arabs, headed by Arif al-Arif Musa Kazem al-Husseini, Jabotinsky and 19 members of the Haganah arrested. Jabotinsky sentenced to 15 years' imprisonment with hard labour and his colleagues, when ratification of the verdicts, General Allenby commuted the sentences to one year to Jabotinsky, and with the commencement of the work of Herbert Samuel, a High Commissioner for Palestine, the residents pardoned the Prisoners on 7 July (July 1920 AD), including Jabotinsky, who may have spent only three months. (15)

\section{JERUSALEM AND THE EVENTS OF NOVEMBER 1921}

by the fourth anniversary of the Balfour Declaration, clashes resumed on the second of November especially in the city of Jerusalem, with Pinhas Rottenberg touring settlements and mixed cities urging 
the Zionists to show vigilance in preparation for November 2, and indeed men have taken Haganah places at sensitive points in mixed cities and settlements, On November 1, Haganah has been introduced 160 members of the city, some of whom stationed in the old town (16), hiding fifteen members of the synagogue in the ghetto. They armed with pistols and hand grenades, and Rachel yennet had smuggled arms into the pockets of her skirt so that the British would not notice it (17), the next day, an Arab mobilization stormed the Jewish neighbourhood. Haganah threw stones at them. They fired their pistols and killed three Arabs. The crowd fled after they killed five Jews in the city. (18)

British police arrived late, arrested three Jews and number of Arabs. Jews sentenced to 10 years imprisonment then released after appeal, while Arab detainees remained in detention (19)

\section{Al-Buraq Revolution In JeRUSAlem (1929 AD)}

The Zionist movement has sought to own the al-Buraq Islamic Wall since 1918, and the Zionist mission headed by Haim Weismann has demanded that the Jews; However, the frictions and Zionist of the feelings of Muslims at the wall began in 1922AD, when large numbers of Jews arrived at the wall during Yom Kippur, accompanied by seats to sit during prayer. The Muslims protested. High Commissioner Herbert Samuel declared a decree forbidding the bringing of seats in the following years. The Jews in 1923AD and 1924AD, but they brought the seats again in 1925AD after the arrival of the new High Commissioner Plumer ( 1925-1928AD) force removed the seats then calmed the problem in 1926AD, 1927AD (20).

In 1928AD, when Jews brought the seats, erected a curtain in front of the wall to separate the men and women, filled the place with tables, cupboards, lamps, etc., the Muslims protested. The authorities demanded the removal of all these tools and the Jews. The police removed them by force, but the Jews They were angry, and the followers of Jabotinsky claimed violence against Muslims, there were adverse reactions, numerous quarrels and clashes (21), souls arose, conferences, meetings, and protests from both sides, and the British Colonial Secretary In the same year a White Paper, which stipulates the commitment of his government to maintain the status of the Wall Buraq, and urged Muslims and Jews to agree among themselves . (22)

On August 2,1929AD, Muslims held a meeting at the Al-Aqsa Mosque in protest against the repeated Jewish attacks on the Al-Buraq Al- Wall, by bringing the forbidden tools and preventing the residents of the Muslim neighbourhood from going to their homes on the Buraq road (23). Jews who came to pray at the wall that day, and wounded some of them (24).

The Sixteenth Zionist Congress, held in Zurich, ended its work on 11 August 1929AD and decided to expand the Jewish Agency, and the right of the Jews to establish their religious rites next to the wailing is immutable, This coincided with the fasting of the ninth of August (according to the Hebrew calendar), the anniversary of the devastation of the temple, and on this occasion the Zionists held a meeting in Tel Aviv (25), and they got a license to march the next day, heading towards the wall of the Buraq and the stories about the number of participants in March a novel that included 600 people(26), The other reported that they were 300(27), and the third reported that the participants were 6000 (28), The Hebrew references were silent on this matter but differed around the organization, some stating that Haganah organized the march(29), and others stated that Jabotinsky followers supervise(30). The researcher is likely to be only three hundred people, from Betar members, based on the fact that the March commander Yermiahu Halfresne(31), and for the confession of a Haganah leader in Jerusalem, that the march betar, and that it protected by pistols and bombs. (32)

The Zionist March moved through the streets of Jerusalem until it arrived near the wall of al-Buraq, and there they lifted the Zionist media, and the participants began to chant the Zionist anthem (HTKFA), chanting (our wall is a wall) (33), ignoring what agreed between Pinha, Rottenberg, the British leadership of didn't lift flags, or walking in military formations or provoking the feelings of Muslims. (34)

The next day (Friday, 16 August 1929) coincided with the anniversary of the Prophet's birthday, and after Friday prayers, worshippers in the Holy Al-Aqsa mosque staged a rally that included about 2,000 people, some from Nablus, and of other areas to participate in the Prophet's birthday celebration, headed for al-Buraq Square, chanting An Islamic wall, they turned the Deacon's table, took out the papers that the Jewish worshippers put in the cracks of the wall, tore them up, and tore the Deacon's clothes.(35) 
The police imposed a curfew in Jerusalem, from sunset to sunrise, and the Governor of Jerusalem declared a decision authorizing the police to separate any gathering in a public place, and to arrest without a warrant anyone from a gathering if he refused or delayed leaving the place, or returned to the rally, and the decision authorized the arrest of anyone found in a public place protecting A knife, dagger, iron stock, and weapon of any kind. (36)

The next day, August 17, a confrontation took place between Arabs and Jews in Jerusalem. A Jew stabbed a stab who died two days later. Eleven Jews and fifteen Arabs were injured (37). The death of the Jewish youth increased tension. His funeral turned into a riot. (38) Friday 23 August There is a rumour that the Jews killed two Arabs, the Arabs rebelled and poured into the yard of the Al-Aqsa Mosque, After Friday prayers, a group of the old town came out, through the gates of Jaffa and Nablus, and began clashes with the Jews. (39)

The Muslim protesters split in two; one headed through the Jaffa Gate to the new town, and they killed four Jews stabbed with knives, they beat others and broke the doors of the shops. Some of them went to the Yemin Moshe neighbourhood. Haganah forces repelled them. An hour later the police opened fire on the demonstrators and dispersed them, The second part of the demonstrators, they turned to the city park on Jaffa Street, the Jews had put the barricades, they stood behind them, they managed to repel Arabs and prevented them from entering the streets where Jews reside, but they managed to enter the George's Lane, stormed homes and killed four Jews(40), as Arab groups coming from the Kfar Shilouah side tried to break into the old city, but failed because of the presence of armed Haganah members.(41)

Arab reinforcements from outside the city, attacking the Hsifr neighbourhood and facing Haganah, suffered losses on both sides, and Jewish policemen attacked the Arab revolutionaries (42), and a British police aircraft moved in the air to scare the demonstrators, make them sense into the attack on Rahafya(43), and to witness the Zionist writer ( Morris Samuel, who witnessed the events, that the acute shortage of police officers forced them to recruit about 100 British residents or visitors as private police, that they were biased towards Jews, and fought in many parts of Jerusalem with them. (44)

The details of Haganah's role in the events of the first day in the city of Jerusalem are not as mentioned in the history of the Haganah (Sefer Tolodot Haganah), and even opposed by leaders in the Haganah, says Yusuf Avidor "I discovered inaccuracies in the Haganah book, which stated that we were ready on Thursday, that is, before the events of the day, which is not true. I was an assistant commander, commander of the old town, and my unit was not ready, The unit recruited just a week ago. I remember that we met on Thursday evening (a week before the explosion of events) ... As we know, the intelligence was weak, we did not know what was happening, and it cost us a lot. On Friday, I went up to a mountain to practice jumping by bike. "I was told by telephone that a large number of rebels gathered at the Dome of the Rock. I quickly went down to the town, contacted the unit members and everyone arrived at the time the British closed all the gates of the old town two hours after the events started." (45).

Arab attack launched a training farm, adjacent to the Jewish girl (Talpiot), was it's exposed, gave Rachel yennet and suffered several Jews, transfer of 37 pieces of various types, and took her to Haganah, to defend the Jewish neighbourhood (46).

Preparations Haganah were not at the required level, Preparations Haganah was not at the required level, intelligence which was a clear deficit, especially in the old town, Officers and leaders of Haganah were not one of them when the events broke out in Jerusalem. An exception of Yitzhak BenZvi arrived one day before the events, he had a Mauser pistol, and Joseph Heckt arrived to take over Haganah in the city till the arrival of Abraham Akar (47).

After the arrival of Abraham Akar, one day was arrested by the British authorities and in possession of a weapon. He took over Haganah leadership in Jerusalem Yusuf Avedore (48).

The Zionists claimed that when the rebels began attacking the neighbourhood (meaa Shearim ) Jewish in Jerusalem, It was not the only three elements of the Haganah, arrived at the last minute, and possession of pistols and several grenades, they were able to repel the revolutionaries (49). This argument contradicts what other Zionists said that "the Arab rebels in Jerusalem armed with pistols (50); isn't possible to imagine the ability of three to repel a large audience if the parties armed. 
In Yemin Moshe neighbourhood Haganah's number, and fired at the protesters, threw a grenade at them and managed to hold them. (51)

Events on the first day in Jerusalem showed a clear imbalance between the Haganah, although the Jerusalem branch had 300 numbers (52). However, the intelligence deficit in the ability of the Haganah to get used to so many. The organization's leaders were surprised that Muslim demonstrators were on their way to the new town, the old as they were expecting (53).

The first day was the death of 17 Jews, who were buried on the evening of the following day (Saturday) quickly because the Arabs shot the participants in the funeral (54).

Haganah leadership in Tel Aviv decided to supply its branch in Jerusalem with more weapons. Ephraim Dekel, Haganah's head of in Tel Aviv and the southern region at that time, stated: "It decided to transfer from Tel Aviv to Jerusalem a black Cannon, In ribbons, our authorities informed us. We intend to send a medical mission, consisting of two doctors and two nurses, and boxes of medicines from Tel Aviv to the Jews in Jerusalem, We need approval and provide us with a Jewish police escort, he agreed to Jaffa District police chief on it, two police officers of the security service appointed to us ,who worked in the police, and we managed to get to Jerusalem, and we brought weapons, When the voice of the black breaks the silence of the night (55).

The deficit was evident in the British police in general Palestine, and this reflected in Jerusalem, where there were 100 British policemen, and with the pressure of Zionist institutions, the authorities agreed to recruit 170 Jewish policemen and 18 demobilized soldiers and called them "temporary police"(56), and the next day the Hajj Amin Husseini and a number of elders have sought clarification to the government about the distribution of weapons, and the recruitment of Jews into the regular teams, the government denied this, but it was found before the Shaw Committee afterwards. On 27 August, the Mufti told Mr Locke by telephone that a large crowd of Arab revolutionaries were in the Al-Aqsa Mosque, They demanded a weapon because the government armed the Jews. Locke decided to disarm the Jews(57). At the same time that the revolution in Jerusalem began to subsume for a whole week, in which the Jews subjected to more than twenty attacks, Haganah managed to repel nine of them, And they were not all very successful. (58)

On August 27, the Zionists attacked the ancient Akasha mosque in Jerusalem, where the tombs of a number of-E-Sahaba buried, damaged the mosque and desecrated the graves of the - E-Sahaba. (59)

The British official statistics of the events concluded that 29 Jews killed, 38 Arabs martyred, 43 Jews injured, and 51 Arabs injured in Jerusalem Throughout the week (60). After the researcher returned to the documents of the National Movement, it found that the number of Muslim martyrs in Jerusalem in these events was 46 martyrs, including four women, Zweiter cited their names and places of residence. (61).

The revolution of Al-Buraq ceased, but the spirit of revolution continued. Jerusalem participated in many confrontations against the British occupation and the Zionists until the Great Palestinian Revolt broke out in 1936. To show the active role of the city of Jerusalem in the revolution.

\section{THE CONCLUSION}

- The researcher reached results most important:

- Jerusalem had an active role in the revolutions of 1920 AD, 1921 AD and 1929AD.

- Britain was very biased to the Zionists and turned a blind eye to many of their practice in Jerusalem but stopped their provocations to the Arabs if they felt a great rejection of the Arabs to those provocations.

- A number of Arabs' martyrs and injury in those revolutions. British forces killed a large number under the affection of maintaining security and public order.

- British official statistics were not accurate, claiming that the number of Arab martyrs in the 1929 revolution was 38, but it turned out that they were 46 martyrs, including four women.

- Haganah had a clear role in confronting the Arab rebels in Jerusalem in the Buraq revolution in 1929AD after the arrival of weapons and ammunition from Tel Aviv under the pretext that it was medicine and medical supplies. 


\section{REFERENCES}

[1] Mahsna M., Reality of Jerusalem, Amant Amman Alkubra, Amman.P.255 (2004).

[2] M. Alrusan, Jerusalem under the British occupation and mandate, $1^{\text {st }}$ ed. Erbid,2001, Ch. 6, p...

[3] A. Abu baker, Jerusalem under the British mandate and banks' unity, 1st ed. Open Jerusalem University, Amman, 2010, Ch. 6, P. 263.

[4] Mahani A., Zionism-British relationships in Palestine 1918-1936, Gaza, Palestine, M.D. The Islamic University of Gaza, Gaza, Pp. 32-46, (2010).

[5] Tirbeen A., Palestine in the British mandate role, Palestinian Encyclopedia, Beirut.2(2)P.1005, (1990).

[6] Saleem M., The Jewish Agency actives in Palestine from its establishment to Israel sate rise, Arabic institution for studies and publishing, Beirut.495 (1982).

[7] Benyahuda I., Shoehat I., The struggle for security and dependence, Masada, Ramat Gang.Pp.53-55 (1974).

[8] Rabeen I., Service log, Mareef Publisher, Tel Aviv.P.14 (1979).

[9] Benyahuda I., Shoehat I., Op. Cit., Pp.53-55.

[10] Saleh M., The military forces and police in Palestine and its role in British policy Implementation, Dar Alnfaes, Amman.P286 (1996).

[11] LevAmy Sh., in straggle recalcitrance, Defence Ministry, Tel Aviv.P16.(n.d.)

[12] Al-handy S., British establishment for the Jewish homeland 1920-1925, Palestinian studies institution, Biuret.P85 (2003).

[13] Ellis H., Israel And The Middel East, The Ronald Press Company, New york, P.95 (1957).

[14] Aghuniam A., The Palestinian national movement, Egyptian General Book Authority, Cairo P.49 (1974).

[15] Abdelzaher M., Zionism and the politics of violence; Ze'ev Jabotensky and his disciples in Israeli politics, Egyptian General book Authority, Cairo Pp.143-144 (1979).

[16] LevAmy Sh., Op. Cit.,Pp.19.(n.d.)

[17] Sahar H., The Peoples Of Israel, The World Publishing, Cleveland And New York P.147 ( 1961)

[18] Grace S., History of Zionism, Palestine Liberation Organization Research Center, Nicosia, p. 55 (1986).

[19] LevAmy Sh., Op. Cit.,Pp.19.(n.d.)

[20] Grace S., Op. Cit., P.205.(n.d.)

[21] Defense M., Hebrew policeman in the period of Mandate, p.92 (n.d.)

[22] Tirbeen A., Op. Cit., Pp.1021 (n.d.)

[23] Grace S., Op. Cit., P.207(n.d.)

[24] Defense M., Op. Cit., P.92 (n.d.)

[25] Grace S., Op. Cit., P.207(n.d.)

[26] Jabbara T., The History of modern Palestine, p.138 ( n.d.)

[27] Ayoshi W., Op. Cit., Pp.69 (n.d.)

[28] Tirbeen A., Op. Cit., Pp.1021 (n.d.)

[29] Defense M., Op. Cit., P.93 (n.d.)

[30] Benyahuda I., Shoehat I., Op. Cit., P.67 (n.d.)

[31] LevAmy Sh., Op. Cit.,P.28.(n.d.)

[32] Afidor Y., organization of Haganah in the events of 1929 events and across; State Army on the Way, p. 22

[33] Benyahuda I., Shoehat I., Op. Cit., P.67 (n.d.)

[34] Al-Khawli H., The Policy of colonialism and Zionism towards Palestine in the first half of the 20th century, p.555 (n.d.)

[35] Aghuniam A., Op. Cit.,P.209 (n.d.)

[36] Saleh M., Op. Cit.,Pp.287-288 (n.d.)

[37] Al-Kayaly A., Op. Cit.,P.203 (n.d.)

[38] LevAmy Sh., Op. Cit.,P.28.(n.d.)

[39] Defense M., Op. Cit., P.93 (n.d.)

[40] LevAmy Sh., Op. Cit.,P.29.(n.d.)

[41] Defense M., Op. Cit., P.93 (n.d.)

[42] Ministry D., Op. Cit., Pp.93-94 (n.d.) 
[43] LevAmy Sh., Op. Cit.,P.29.(n.d.)

[44] Saleh M., Op. Cit., P.220 (n.d.)

[45] Afidor Y., Op. Cit., P.22 (n.d.)

[46] Sahar H., Op. Cit., p.149 (n.d.)

[47] Afidor Y., Op. Cit., P.23 (n.d.)

[48] Afidor Y., Op. Cit., P.23 (n.d.)

[49] Omekam P., Resuscitation under the British 1918-1929, p. 53.(n.d.)

[50] Diakil E., Information system Activities (Hachai),from the memorandum of the commander of the Information System, p. 50.(n.d.)

[51] Omekam P., Op. Cit., P.53 (n.d.)

[52] Afidor Y., Op. Cit., P.23 (n.d.)

[53] Benyahuda I., Shoehat I., Op. Cit., P.68 (n.d.)

[54] Ministry D., Op. Cit., Pp.93-94 (n.d.)

[55] Diakil E., Op. Cit., Pp.50-52 (n.d.)

[56] LevAmy Sh., Op. Cit.,P.30.(n.d.)

[57] Aghuniam A., Op. Cit.,P.198 (n.d.)

[58] Afidor Y., Op. Cit., Pp.22-23 (n.d.)

[59] Al-Kayaly A., Op. Cit., P.205 (n.d.)

[60] Hurst D., Weapon and Olive Branch and the roots of violence in the Middle East, P.224 (n.d.)

[61] Zoiter A., Documents Of The Palestinian National Movement 1918-1939, Pp.329-330 (n.d.)

\section{AUTHOR'S BIOGRAPHY}

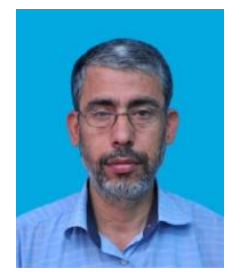

Dr Zakaria Ibrahim Hassan Al-Senwar, a Palestinian, born in 1965, In KhanYoun is refugee camp in Gaza Strip, holds a PhD in modern and contemporary history from the Institute of Arab Research and Studies in Cairo in 2006.He became a professor in 2013.He has written 12 books individually or in partnership. He has 25 scholarly research papers, published in scientific journals or scientific conferences. He supervised dozens of scientific theses for referee a master's degree and $\mathrm{PhD}$ in a number of Palestinian and Arab universities. He received the Arab Prize for Heritage, that organized by the Educational Organization (ALECSO) in 2013.

Citation: Dr. Zakaria Ibrahim Al-Senwar. "The Role of Jerusalem in the Revolutions against the British Occupation and the Zionists (1920-1929 AD)". International Journal of Humanities Social Sciences and Education (IJHSSE), vol 5, no.12, 2018, pp. 62-68. doi:http://dx.doi.org/10.20431/2349-0381.0512007.

Copyright: (C) 2018 Authors. This is an open-access article distributed under the terms of the Creative Commons Attribution License, which permits unrestricted use, distribution, and reproduction in any medium, provided the original author and source are credited. 